\title{
Effect of a starter diet supplementation with mannan- oligosaccharide or inulin on health status, caecal metabolism, digestibility of nutrients and growth of early weaned rabbits
}

\author{
Z. Volek ${ }^{1 \dagger}$, M. Marounek ${ }^{1,2}$ and V. Skřivanová ${ }^{1}$ \\ ${ }^{1}$ Research Institute of Animal Production, CZ-104 01 Prague 10, Czech Republic; ${ }^{2}$ Institute of Animal Physiology and Genetics, Czech Academy of Sciences, \\ CZ-142 20 Prague 4, Czech Republic
}

(Received 14 April 2006; Accepted 21 November 2006)

\begin{abstract}
The effect of a dietary supplementation with mannan-oligosaccharide (MOS, Bio-Mos, Alltech Inc.) and inulin (Frutafit $\left.{ }^{\circledR} I Q\right)$ on growth, health, and caecal traits was studied on 348 rabbits $\left(\right.$ Hyplus $\left.{ }^{\circledR}\right)$, weaned at 25 days of age. Three hundred and thirty rabbits (110 per group) were used for the health status and growth performance trial, while 18 rabbits (six per group) were used for caecal metabolism evaluation at the age of 42 days of age. Three diets were formulated: C (control), M (0.3\% MOS) and I diet (4\% inulin). Digestibility of the diets was measured in 10 rabbits per group between 36 and 40 days of age. The control diet was fed to rabbits of the $C$ group from weaning to 74 days of age (slaughter). Diets $M$ and I were fed to rabbits of the respective group from weaning to 46 days of age, then were fed with control diet till slaughter. From 25 to 46 days of age, the weight gain was slightly higher in control rabbits $(\mathrm{P}=0.11)$, while no differences were recorded for the whole period. No differences among groups in the mortality, which was high due to an enteropathy-infected environment, were significant. The lowest morbidity $(P=0.05)$ as well as the health risk index were recorded in rabbits fed the diet with inulin $(P=0.03)$. After change of diet, the health risk index increased in the rabbits previously fed the diet with additives, thereby no significant differences in the health status were recorded for the whole period. Total caecal volatile fatty acids concentration was higher $(\mathrm{P}<0.01)$ and the $\mathrm{pH}$ $(\mathrm{P}<0.01)$ and ammonia concentration $(\mathrm{P}=0.01)$ lower in rabbits fed the inulin diet than in other rabbits. In these animals, acetate molar proportion was higher $(\mathrm{P}=0.01)$ and that of propionate as well as the propionate/butyrate ratio significantly lower than in other rabbits. Butyrate molar proportion was higher in rabbits fed the diet with MOS $(\mathrm{P}<0.01)$. In rabbits fed the inulin diet a higher activity of inulinase was recorded $(\mathrm{P}<0.001)$ than in other rabbits. A significantly lower digestibility of cellulose was observed in rabbits fed the diet with MOS. The results of our study suggest the importance of using inulin-type fructans in the nutrition of young rabbits. The higher health risk index of rabbits after change of diets indicates that prebiotics should be given for a longer time during the fattening period.
\end{abstract}

Keywords: health, inulin, mannan-oligosaccharide, microbial activity, rabbits

\section{Introduction}

Early weaning of young rabbits ( $<26$ days) has been proposed as a means of reducing does energy deficit by decreasing milk energy output and providing adequate nutrition of young rabbits as soon as they begin to eat solid feed (Pascual, 2001; Gidenne and Fortun-Lamothe, 2002; Xiccato et al., 2004). To use this method, however, the nutritional demands of young rabbits must be fully known. To date, several authors have dealt with nutrition of early weaned rabbits and some interesting results

\footnotetext{
${ }^{\dagger}$ E-mail: volek.zdenek@vuzv.cz
}

regarding enzyme supplementation and heat processing, a suitable source of protein and energy or fibre and energy level in the starter diet have been reported (Gutiérrez et al., 2002a and b and 2003; Xiccato et al., 2003; Nicodemus et al., 2004). However, the main problem is still the digestive health of early weaned rabbits. Faced with a specific pathology, early weaning tended to increase the health risk (Gidenne and Fortun-Lamothe, 2004; Volek et al., 2005). The most common method of prevention of digestive disorders in rabbits is the use of a feed supplemented with an antibiotic. As antibiotic growth promoters have been banned in the European Union, there is a need for effective alternatives which can be used in rabbits. 
It is possible to increase the resistance of early weaned rabbits to digestive troubles through dietary supplementation with mannan-oligosaccharide (MOS) or inulin-type fructans (Spring et al., 2000). MOS is derived from the outer cell wall of the yeast Saccharomyces cerevisiae. It was shown that MOS had the ability to bind pathogenic bacteria expressing type-1 fimbriae such as Salmonella spp. or Escherichia coli (Spring et al., 2000). In traditionally weaned rabbits (between 28 and 35 days of age), the addition of MOS to a diet stimulated villi development and caecal volatile fatty acid concentration and reduced caecal $\mathrm{pH}$ and mortality (Fonseca et al., 2004; Pinheiro et al., 2004). Also fructo-oligosaccharides have been widely studied, mainly due to their beneficial effect on health of animals (Flickinger et al., 2003). Inulin is a polysaccharide composed of $\beta-2,1$-linked fructosyl moieties, mostly with a terminal glucose. Most of the inulin commercially available today is extracted from chicory roots. These types of inulin have a degree of polymerisation of 2 to 60 , with an average ranging from 9 to 25 (Meyer et al., 2004). In rabbits, the addition of inulin to diet had a beneficial effect on caecal fermentative activity (Morisse et al., 1993; Maertens et al., 2004; Volek et al., 2005), which could improve the protection of weaned rabbits against common pathogens. However, effect of dietary supplementation with MOS or inulin on digestive health and growth performance of early weaned rabbits is still insufficiently documented. Therefore, the aim of this study was to evaluate the effect of dietary supplementation with either mannan-oligosaccharide (MOS, Bio-Mos ${ }^{\circledR}$, Alltech Inc.) or inulin (Frutafit ${ }^{\circledR}$ IQ, Sensus, Netherlands) on the health status, microbial activity (fermentative activity, fibrolytic activity, fibre digestion), digestibility of nutrients and growth of early weaned rabbits.

\section{Material and methods}

\section{Experimental diets}

Three experimental diets were formulated: diet C (control, without additives), diet $\mathrm{M}$ (supplemented with $0.3 \%$ mannan-oligosaccharide), and diet I (supplemented with 4\% inulin). Common feed components were used (Table 1). The diets were similar in the level of crude protein $(C P)$, fat and fibre fraction but differed in the level of starch and fructans (Table 2). Both diet $\mathrm{C}$ and diet $\mathrm{M}$ contained more starch and less fructans than diet I (130 and 7, 134 and 7, 120 and $47 \mathrm{~g} / \mathrm{kg}$, respectively). Mannan-oligosaccharide (Bio-Mos, Alltech, Inc., Nicholasville, KY) was added to the vitamin pre-mix in substitution of the pre-mix support (wheat flour), and then included in the diet M. The diet I was supplemented with $4 \%$ chicory inulin, at the expense of wheat bran, by means of Frutafit ${ }^{\circledR}$ IQ (SENSUS, 4704 RG Roosendaal, The Netherlands). Frutafit ${ }^{\circledR}$ IQ is the instantised version of powdered inulin. According to Meyer et al. (2004), about $85 \%$ of inulin molecules in the Frutafit ${ }^{\circledR}$ IQ consist of six or more glycosyl residues. In accordance with recent results (Gutiérrez et al., 2003; Xiccato et al., 2003; Volek
Table 1 Ingredients (\%) of control (C), mannan-oligosaccharide (M) and inulin (I) diet

\begin{tabular}{|c|c|c|c|}
\hline & \multicolumn{3}{|c|}{ Diet } \\
\hline & C & M & I \\
\hline \multicolumn{4}{|l|}{ Ingredients (\%) } \\
\hline Alfalfa meal & 28 & 28 & 28 \\
\hline Sunflower meal & 19 & 19 & 19 \\
\hline Wheat bran & 24 & 24 & 20 \\
\hline Sugar-beet pulp & 4 & 4 & 4 \\
\hline Oats & 13 & 13 & 13 \\
\hline Barley & 7 & 7 & 7 \\
\hline Rapeseed oil & 2 & 2 & 2 \\
\hline Inulin (Frutafit ${ }^{\circledR} \mathrm{IQ}$ ) & 0 & 0 & 4 \\
\hline Vitamin supplement $^{\dagger}$ & 1 & $1^{\ddagger}$ & 1 \\
\hline Dicalcium phosphate & 0.5 & 0.5 & 0.5 \\
\hline Limestone & 1 & 1 & 1 \\
\hline Salt & 0.5 & 0.5 & 0.5 \\
\hline
\end{tabular}

${ }^{\dagger}$ Per kg supplement: vitamin A-1 $200000 \mathrm{IU}$; vitamin $D_{3}-200000 \mathrm{IU}$; vitamin $\mathrm{E}-5 \mathrm{~g}$; Vitamin $\mathrm{K}_{3}-0.2 \mathrm{~g}$; vitamin $\mathrm{B}_{1}-0.3 \mathrm{~g}$; vitamin $\mathrm{B}_{2}-0.7 \mathrm{~g}$; vitamin $\mathrm{B}_{6}-0.4 \mathrm{~g}$; niacinamide- $5 \mathrm{~g}$; Ca-pantothenate- $2 \mathrm{~g}$; folic acid- $0.17 \mathrm{~g}$; biotin- $20 \mathrm{mg}$; vitamin $\mathrm{B}_{12}-2 \mathrm{mg}$; choline- $60 \mathrm{~g}$; lysine- $25 \mathrm{~g}$; DL- methionine- $100 \mathrm{~g}$.

‡ Supplemented with $0.3 \%$ mannan-oligosaccharide (BIO-MOS, Alltech, Inc., Nicholasville, KY).

et al., 2005) regarding some aspects of the formulation of starter diet for early weaned rabbits, the diets contained sunflower meal instead of soya-bean meal, a higher level of fat, and a lower level of starch and dietary pectin. The anticoccidial Robenidine $(66 \mathrm{mg} / \mathrm{kg}$ diet) was used. No other antimicrobials were used during trial.

Table 2 Chemical composition $(\mathrm{g} / \mathrm{kg})$ of control (C), mannan-oligosaccharide (M) and inulin (I) diet

\begin{tabular}{|c|c|c|c|}
\hline & \multicolumn{3}{|c|}{ Diet } \\
\hline & $\mathrm{C}$ & M & I \\
\hline \multicolumn{4}{|l|}{ Chemical composition (g/kg) } \\
\hline Dry matter & 907 & 910 & 903 \\
\hline Crude protein & 169 & 165 & 163 \\
\hline $\mathrm{NDF}^{\dagger}$ & 378 & 375 & 369 \\
\hline${\text { Lignocellulose }(A D F)^{\dagger}}^{\dagger}$ & 224 & 229 & 225 \\
\hline Lignins $(A D L)^{\dagger}$ & 56 & 58 & 60 \\
\hline Hemicelluloses (NDF - ADF) & 154 & 146 & 144 \\
\hline Cellulose (ADF - ADL) & 168 & 171 & 165 \\
\hline ADL/cellulose ratio & 0.33 & 0.33 & 0.36 \\
\hline Pectins (water insoluble) ${ }^{\ddagger}$ & 50 & 50 & 48 \\
\hline Fructans $s^{\S}$ & 7 & 7 & 47 \\
\hline Starch & 130 & 134 & 120 \\
\hline NNCC & 280 & 294 & 291 \\
\hline Fat & 45 & 44 & 42 \\
\hline Digestible energy (MJ/kg) & 10.2 & 10.2 & 9.8 \\
\hline
\end{tabular}

${ }^{\dagger}$ According to the sequential method of Van Soest et al. (1991); NDF = neutral-detergent fibre, $A D F=$ acid-detergent fibre, $A D L=$ acid-detergent lignin.

${ }^{\ddagger}$ Calculated according to Gidenne (2003).

${ }^{\S}$ Calculated according to Knudsen (1997).

"Non-nitrogenous cellular content $=$ organic mater - NDF - CP.

" Calculated according to Maertens et al. (2002). 
Health status and growth performance trial

A total of 330 Hyplus ${ }^{\circledR}$ rabbits $(616 \pm 79 \mathrm{~g})$, weaned at 25 days of age, were randomly allocated into three groups (group C, M and I). All rabbits were individually ear tagged. The experiment was carried out under practical conditions on a commercial farm, in spring 2005. At weaning, rabbits were moved from the maternal sector to the fattening sector and put in all-wire cages $(30 \times 30 \times 33 \mathrm{~cm})$, two per cage. A minimum environmental temperature was maintained at $16^{\circ} \mathrm{C}$ during the experiment.

The control diet (diet C, without additives) was fed to rabbits of the $C$ group from weaning to slaughter at 74 days of age. Diet M (MOS) and diet I (inulin) were fed to rabbits of the respective group (group $M$ and group I) from weaning to 46 days of age, then rabbits received control diet till slaughter.

The diets and water were offered ad libitum to all rabbits during the entire experimental period. As the trial was performed on a commercial farm without the possibility of measuring feed intake individually, consumption of feed was measured weekly per group, and therefore statistical evaluation of feed intake was not possible. Feed intake (g per rabbit per day) was calculated as follows: consumption of feed was divided by both numbers of rabbits within period and days within period (Volek et al., 2006). Rabbits which died during period were excluded from calculation. Animals were individually weighed every week.

Mortality was recorded every day; morbidity was recorded weekly. Health status was evaluated according to European Group on Rabbit Nutrition (Fernández-Carmona et al., 2005). It means that morbidity corresponds to sick rabbits (but still alive within a period) showing digestive troubles or severe loss of weight during a week. An animal was considered morbid only once (within period), even if diarrhoea lasted several days. The 'health risk index' was the sum of morbid and dead rabbits, knowing that each animal was considered only once (classed either dead or morbid). Dead rabbits were subjected to autopsy in the State Veterinary Institute in Prague and examined using ISO methods (http://www.iso.org).

\section{Microbial activity}

A total of 18 Hyplus $^{\circledR}$ rabbits ( $636 \pm 45 \mathrm{~g}$ ), 25 days old at the beginning of the trial, were used for caecal digesta evaluation. Rabbits were assigned at random to the three experimental diets $(C, M$, and I diet) and put in all-wire cages $\left(0.16 \mathrm{~m}^{2}\right)$, one per cage, in a climate-controlled room. Environmental conditions were as follows: temperature $16 \pm 1{ }^{\circ} \mathrm{C}$, relative humidity ca. $65 \%$. Both feed and water were offered ad libitum. Rabbits were slaughtered at the age of 42 days. After laparatomy, the caeca were excised and weighed. The caeca were emptied by squeezing, the $\mathrm{pH}$ of the caecal digesta was measured immediately, and caecal contents were weighed. For analyses of caecal volatile fatty acid and ammonia concentrations, portion of caecal digesta was diluted 1:2 with distilled water, and $50 \mathrm{mg}$ of mercury II chloride were added to inactivate microbial growth. Other portions of caecal digesta was frozen and kept under $\mathrm{CO}_{2}$ at $-80^{\circ} \mathrm{C}$ until analysed (bacterial fibrolytic activity) or used for dry matter determination. All animals were healthy, i.e. no diarrhoea or loss of live weight were observed.

\section{Apparent digestibility trials}

A total of 30 Hyplus $^{\circledR}$ rabbits $(629 \pm 40 \mathrm{~g}), 25$ days old at the beginning of the experiment, were used in order to determine the coefficient of the total tract apparent digestibility of the experimental diets. Rabbits were assigned at random to three experimental diets (C, M, and I diet). Animals were individually housed in digestibility cages $(34.5 \times 39.5 \times 40.0 \mathrm{~cm})$. Feed and water were offered $\mathrm{ad}$ libitum during the whole experimental period. The environmental conditions were as follows: temperature 16 to $18^{\circ} \mathrm{C}$, relative humidity ca. $65 \%$. Following 11 days of an adaptation period, the feed intake and total faecal output (caecotrophy was not prevented) were recorded from 36 to 40 days of age for each rabbit according to the European reference method (Perez et al., 1995). All animals were healthy, i.e. no diarrhoea, low feed intake or loss of live weight were registered.

\section{Analytical methods}

$\mathrm{CP}$, fat and starch content were determined by the Association of Official Analytical Chemists (AOAC) procedure (1980): contents of $C P(6.25 \times N$ by the AOAC procedure 2.055) and fat (AOAC procedure 7.052) in the feed and faeces were determined employing instruments Kjeltec Auto 1030 Analyser and Soxtec 1043 from Tecator Comp. (Sweden), respectively. Starch was determined by the Ewers method (AOAC procedure 14.032). Dry matter was determined by drying of samples of the feed, digesta and faeces at $105^{\circ} \mathrm{C}$ to constant weight. Neutral-detergent fibre (NDF), acid-detergent fibre (ADF) and acid-detergent lignin (ADL) were determined according to the procedure of Van Soest et al. (1991), using Fibertec 2010 (Tecator Comp., Sweden). Water-insoluble pectins, fructans, as well as digestible energy were calculated from tables (Knudsen, 1997; Maertens et al., 2002; Gidenne, 2003). The non-nitrogenous cellular content (NNCC), which includes pectins, starch, oligosaccharides and free sugars, was estimated by difference according to the equation: NNCC $=0 M-C P-N D F$ (Gidenne and Fortun-Lamothe, 2004), where OM is dry matter minus ash. Caecal contents were diluted with distilled water 1:2 and total volatile fatty acids (VFA) were determined by titration after steam distillation. The VFA molar percentages were estimated by gas chromatography at $140^{\circ} \mathrm{C}$, employing a column of the Chromosorb WAW with $15 \%$ SP 1220 and $1 \% \mathrm{H}_{3} \mathrm{PO}_{4}$ (Supelco). Ammonia was determined colorimetrically with Nessler reagent after prior separation from interfering compounds by microdiffusion in Conway units (Conway, 1957). Activities of cellulase (EC 3.2.1.4), xylanase (EC 3.2.1.32), pectinase (EC 3.2.1.15) and inulinase (EC 3.2.1.7) were assayed according to Kopečný and Bartoš (1990) using carboxymethylcellulose 
(sodium salt, low viscosity), wood xylan, citrus pectin and inulin as substrates at concentration of $4 \mathrm{mg} / \mathrm{ml}$. Contents of the caecum were diluted with a $50 \mathrm{mmol} / \mathrm{l}$ phosphate buffer $(\mathrm{pH}$ 7.0). For the incubation, $1 \mathrm{ml}$ of substrate and $1 \mathrm{ml}$ of digesta were diluted and mixed. The incubation was performed at $39^{\circ} \mathrm{C}$ for $1 \mathrm{~h}$, and $2 \mathrm{~h}$ in the case of the determination of cellulolytic activity. It was terminated by adding $1 \mathrm{ml}$ of $0.3 \mathrm{~mol} / / \mathrm{Ba}(\mathrm{OH})_{2}$ and $1 \mathrm{ml}$ of $0.3 \mathrm{~mol} / / \mathrm{ZnSO}_{4}$. The precipitate was removed by centrifugation $(10000 \mathrm{~g}$, $15 \mathrm{~min}$ ) and reducing sugars were quantified spectrophotometrically at $410 \mathrm{~nm}$ by a $p$-hydroxybenzoic acid hydrazide method (Lever, 1977). The quantity of released sugars was expressed as micromole of reducing sugars per gram of dry matter of caecal content and per hour.

\section{Statistical analyses}

For a statistical analysis of growth rate, only data from healthy rabbits were used (initial number of rabbits at weaning minus morbidity and mortality) (Table 3), in order to evaluate the effect of diets on growth rate corrected for the influence of sick rabbits (Gidenne et al., 2000; Volek et al., 2006). Data on effect of the diet on growth performance, caecal parameters and digestibility coefficient were analysed using the GLM procedure of Statistical Analysis Systems Institute (2001). Sheffe's test was used for mean comparison where appropriate. Data on mortality and morbidity were analysed using the $\chi^{2}$ test. The statistical significance was considered as $P<0.05$.

\section{Results}

Diets, growth performance and health status In accordance with the objectives of the experiment, the three experimental diets were similar in their chemical composition (Table 2). They differed in the level of starch and fructans because of the addition of $4 \%$ chicory inulin into the diet I at the expense of wheat bran content (Table 1).

During the starter period ( 25 to 46 days of age), the weight gain tended to be higher in control rabbits than in other groups (35.7, 32.3 and $33.3 \mathrm{~g} /$ day in the group C, M and $\mathrm{I}$, respectively; $P=0.11$ ), while no differences were recorded for the whole period (Table 3). There were no substantial differences in the average feed intake during the entire fattening period.

No differences among groups in mortality rate were significant, although a lower mortality rate in rabbits fed diet with mannan-oligosaccharide was observed $(21.8,26.4$ and $30.9 \%$ in rabbits fed $\mathrm{M}, \mathrm{I}$ and control diet, respectively; Table 4). In dead rabbits, Clostridium perfringens, Klebsiella pneumoniae and non-hemorrhagic E. coli were identified potential bacterial pathogens in the intestine and Pasteurella multocida, Klebsiella pneumoniae and non-hemorrhagic $E$. coli in other organs. Pathogenicity of $E$. coli isolates was not examined. Also coccidiosis was recorded (Eimeria magna, Eimeria media, Eimeria perforans). On the other hand, some differences were observed in both morbidity and the health risk index of young rabbits. The lowest morbidity $(P=0.05)$ as well as the health risk index were recorded in rabbits fed diet with inulin (40.0, 46.4 and $55.5 \%$ in rabbits fed $\mathrm{I}, \mathrm{M}$ and control diet, respectively; $P=0.03$ ). After a change of diet (at 46 days of age), however, the health risk index increased in the rabbits previously fed diet with additives (mannan-oligosaccharide or inulin), therefore no significant differences in the health status of rabbits were recorded for the entire fattening period.

Caecal traits, microbial activity, and digestibility of experimental diets

The effect of the dietary treatments on several caecal traits and microbial activity is shown in Table 5. No significant

Table 3 Growth performance of early weaned rabbits fed control (C), mannan-oligosaccharide (M) and inulin (I) diet

\begin{tabular}{|c|c|c|c|c|c|}
\hline & \multicolumn{3}{|c|}{ Diet } & \multirow[b]{2}{*}{$\mathrm{RMSE}^{\dagger}$} & \multirow[b]{2}{*}{ Significance } \\
\hline & $\mathrm{C}$ & M & 1 & & \\
\hline Rabbits $^{\ddagger}$ & 45 & 49 & 51 & & \\
\hline \multicolumn{6}{|l|}{ Live weight (g) } \\
\hline at 25 days & 612 & 622 & 619 & 80 & \\
\hline at 46 days & 1361 & 1301 & 1318 & 197 & \\
\hline at 74 days & 2505 & 2453 & 2502 & 287 & \\
\hline \multicolumn{6}{|l|}{ Period: $25-46$ day of age } \\
\hline Weight gain (g/day) & 35.7 & 32.3 & 33.3 & 7.83 & \\
\hline Feed intake (g/day) $)^{\S}$ & 57.8 & 58.1 & 60.0 & - & \\
\hline \multicolumn{6}{|l|}{ Period: $46-74$ day of age } \\
\hline Weight gain (g/day) & 40.9 & 41.1 & 42.3 & 8.22 & \\
\hline Feed intake (g/day) $)^{\S}$ & 149.8 & 136.2 & 146.3 & - & \\
\hline \multicolumn{6}{|l|}{ Period: $25-74$ day of age } \\
\hline Weight gain (g/day) & 38.6 & 37.4 & 38.4 & 5.40 & \\
\hline Feed intake $(g / \text { day })^{\S}$ & 110.4 & 102.7 & 109.3 & - & \\
\hline
\end{tabular}

${ }^{\dagger}$ RMSE $=$ root mean square error.

${ }^{\ddagger} n=$ initial number of rabbits at weaning (110 per group) minus mortality and morbidity.

${ }^{\S}$ Average data of groups not analysed statistically. 
Table 4 Health status of early weaned rabbits ${ }^{\dagger}$ fed control (C), mannan-oligosaccharide (M) and inulin (I) diet

\begin{tabular}{|c|c|c|c|c|}
\hline & \multicolumn{3}{|c|}{ Diet } & \multirow[b]{2}{*}{ Significance } \\
\hline & $\mathrm{C}$ & $M$ & I & \\
\hline Initial number of rabbits & 110 & 110 & 110 & \\
\hline \multicolumn{5}{|l|}{ Period: $25-46$ day of age } \\
\hline Mortality \% $(n)^{\ddagger}$ & $30.9(34)$ & $21.8(24)$ & $26.4(29)$ & \\
\hline Morbidity \% (n) & $24.6(27)$ & $24.6(27)$ & $13.6(15)$ & \\
\hline Health risk index $\%(n)$ & $55.5(61)$ & $46.4(51)$ & $40.0(44)$ & * \\
\hline \multicolumn{5}{|l|}{ Period: $25-74$ day of age } \\
\hline Mortality $\%(n)$ & $34.6(38)$ & $29.1(32)$ & $36.4(40)$ & \\
\hline Morbidity \% (n) & $24.6(27)$ & $26.4(29)$ & $17.3(19)$ & \\
\hline Health risk index $\%(n)$ & $59.1(65)$ & $55.5(61)$ & $53.6(59)$ & \\
\hline
\end{tabular}

${ }^{\dagger} 110$ rabbits per group at the beginning of the trial.

${ }^{\ddagger}$ Numbers of dead and sick rabbits are given in parentheses.

effect of the diets was detected on caecum relative weight and its content. However, strong changes were observed in caecal microbial activity. Total caecal VFA concentration was significantly higher $(P<0.01)$ and the $\mathrm{pH}$ lower in rabbits fed inulin diet than in the caecum of other rabbits $(5.85,5.98$, and 5.68 in rabbits fed control, $\mathrm{M}$ and I diet, respectively; $P<0.01$ ). Also caecal ammonia concentration strongly decreased when rabbits received diet with inulin (143.5, 142.6 and $102.6 \mu \mathrm{g} / \mathrm{ml}$ in rabbits fed control, M and I diet, respectively; $P=0.01$ ). Acetate molar proportion was higher $(P=0.01)$ and that of propionate and other VFA as well as the propionate/butyrate ratio significantly lower in rabbits fed diet supplemented with inulin than in other rabbits. Butyrate molar proportion was significantly higher in rabbits fed the diet with mannanoligosaccharide $(P<0.01)$. The other differences were detected on the caecal bacterial fibrolytic activity. A significantly higher activity of inulinase was recorded in rabbits fed the diet supplemented with inulin. The activity of cellulase tended to be lower in rabbits fed the diet supplemented with mannan-oligosaccharide $(P=0.10)$.

Whole tract digestibility coefficients of experimental diets are shown in Table 6. A lower digestibility of cellulose $(P=0.03)$ was observed in rabbits fed the diet

Table 5 Caecal parameters and caecal microbial activity in early weaned rabbits fed control (C), mannan-oligosaccharide (M) or inulin (I) diet at 42 days of age

\begin{tabular}{|c|c|c|c|c|c|}
\hline & \multicolumn{3}{|c|}{ Diet } & \multirow[b]{2}{*}{$\operatorname{RMSE}^{\dagger}$} & \multirow[b]{2}{*}{ Significance } \\
\hline & C & M & 1 & & \\
\hline Live weight (g) & 1374 & 1343 & 1339 & 41 & \\
\hline \multicolumn{6}{|l|}{ Caecum } \\
\hline Full organ $(\%$ LW) & 7.91 & 8.28 & 9.16 & 1.12 & \\
\hline Empty organ (\% LW) & 2.34 & 2.49 & 2.58 & 0.34 & \\
\hline Fresh content (\% LW) & 5.56 & 5.79 & 6.59 & 0.91 & \\
\hline Dry matter (\%) & 24.8 & 23.4 & 23.4 & 1.8 & \\
\hline $\mathrm{pH}$ & $5.85^{\mathrm{ab}}$ & $5.98^{\mathrm{a}}$ & $5.68^{\mathrm{b}}$ & 0.12 & ** \\
\hline Total VFA (mmol/l) & $99.3^{\mathrm{a}}$ & $97.7^{\mathrm{a}}$ & $125.5^{\mathrm{b}}$ & 14.4 & ** \\
\hline Acetate (mol \%) & $69.2^{\mathrm{a}}$ & $67.8^{\mathrm{a}}$ & $76.4^{\mathrm{b}}$ & 4.1 & * \\
\hline Propionate (mol \%) & $5.9^{\mathrm{a}}$ & $6.4^{\mathrm{a}}$ & $4.6^{\mathrm{b}}$ & 0.6 & $* * *$ \\
\hline Butyrate (mol \%) & $17.0^{\mathrm{a}}$ & $20.3^{\mathrm{b}}$ & $16.9^{\mathrm{a}}$ & 1.4 & ** \\
\hline Propionate/butyrate ratio & $0.34^{\mathrm{a}}$ & $0.32^{\mathrm{ab}}$ & $0.28^{\mathrm{b}}$ & 0.03 & * \\
\hline Other VFA (mol \%) & $8.1^{\mathrm{a}}$ & $7.7^{\mathrm{a}}$ & $3.2^{\mathrm{b}}$ & 1.5 & $* * *$ \\
\hline $\mathrm{NH}_{4}^{+}(\mu \mathrm{g} / \mathrm{ml})$ & $143.5^{\mathrm{a}}$ & $142.6^{\mathrm{a}}$ & $102.6^{\mathrm{b}}$ & 21.1 & * \\
\hline \multicolumn{6}{|l|}{ Enzymatic activity $^{\ddagger}$} \\
\hline Pectinase (EC 3.2.1.15) & 102 & 117 & 115 & 20 & \\
\hline Xylanase (EC 3.2.1.32) & 64 & 62 & 64 & 17 & \\
\hline Inulinase (EC 3.2.1.7) & $25^{\mathrm{a}}$ & $19^{\mathrm{a}}$ & $69^{b}$ & 8 & $* * *$ \\
\hline Cellulase (EC 3.2.1.4) & 10 & 9 & 13 & 3 & \\
\hline
\end{tabular}

${ }^{a, b}$ Values in the same row with unlike superscript differ significantly $(P<0.05)$.

${ }^{\dagger}$ RMSE $=$ root mean square error.

${ }^{\ddagger}$ The assay was based on the increase in reducing power, calibrated by corresponding monomeric sugars. The activity was expressed as micromole of reducing sugars per gram of dry matter of caecal content per hour. 
supplemented with mannan-oligosaccharide than in rabbits fed the other diets. No significant differences were recorded in mean live weight and feed intake during digestibility measurements.

\section{Discussion}

In the present study we observed substantial differences in the caecal metabolism in rabbits (Table 5). Compared with the control and MOS diet, the inulin addition strongly influenced the caecal fermentative activity (VFA, pH, ammonia, fermentation pattern) in a beneficial way, which is in agreement with previous studies on rabbits (Morisse et al., 1993; Maertens et al., 2004; Volek et al., 2005) or rats (Juśkiewicz et al., 2004 and 2005). Whatever the diet, the activity of pectinase was higher than the activities of other fibrolytic enzymes (xylanase, inulinase, cellulase), which is in agreement with the hierarchy in fibrolytic activities reported in other studies (Marounek et al., 1995; Gidenne et al., 2002). In rabbits fed the diet supplemented with mannan-oligosaccharide, we found the lowest activity of cellulase $(P=0.10)$ in comparison with other groups. Some negative effects of MOS on the activity of caecal microflora were observed in turkeys. Juśkiewicz et al. (2003) reported a decrease in the bacterial glycolytic activity (especially in $\alpha$-glucosidase, $\alpha$-galactosidase and $\beta$-galactosidase activities) in the caecal digesta of young turkeys fed diets with MOS. In our study, a significantly higher activity of inulinase was recorded in rabbits fed the diet with inulin, which apparently corresponds to a high caecal fermentative activity in these animals. The results of our study indicated a very good utilisation of inulin-type fructans by the caecal microflora of rabbits.

In the present study we found some differences in the digestibility of diets (Table 6). A significantly lower digestibility coefficient of cellulose was observed in rabbits fed the diet supplemented with MOS. Similarly, a significantly lower digestibility coefficient of crude fibre was observed in the growing pigs fed a diet with MOS in comparison with control pigs (Lipiński et al., 2005). In our study, lower digestibility of cellulose can be explained by lower cellulolytic activity observed in the caecum of these rabbits (Table 5).

Supplementation of diets with mannan-oligosaccharide or inulin had no effect on the rabbit growth, except a slightly lower weight gain during starter period in comparison with rabbits fed the control diet $(P=0.11$; Table 3$)$. Similarly, no significant effect of dietary supplementation with MOS or fructo-oligosaccharides on the weight gain of rabbits was observed in other studies (Luick et al., 1992; Scapinello et al., 2001; Fonseca et al., 2004). There were no substantial differences among groups in average feed intake values for the entire fattening period.

No mortality was registered before 30 days of age. On the contrary, mortality rate increased sharply between 32 and 46 days of age. There were no significant differences among groups in mortality during starter period ( 25 to 46 days of age), although it is noteworthy that a lower mortality rate in rabbits fed the diet with mannan-oligosaccharides compared with the control diet occurred (Table 4). Fonseca et al. (2004) reported a significant reduction of mortality rate when traditionally weaned rabbits were fed a diet supplemented with mannan-oligosaccharide during the entire fattening period, but they used a larger number of animals in groups. In our study rabbit mortality was associated with specific enteropathy. A higher susceptibility of early weaned rabbits to a specific pathology, and thereby a high health risk index observed in this study corresponds with other studies (Gidenne and Fortun-Lamothe, 2004; Volek et al., 2005), where no antibiotics were used. As mentioned above, coccidiosis was also observed. In the present study we used the anticoccidial Robenidine

Table 6 Total tract apparent digestibility (TTAD) of control (C), mannan-oligosaccharide (M) and inulin (I) diet

\begin{tabular}{|c|c|c|c|c|c|}
\hline & \multicolumn{3}{|c|}{ Diet } & \multirow[b]{2}{*}{$\mathrm{RMSE}^{\dagger}$} & \multirow[b]{2}{*}{ Significance } \\
\hline & $\mathrm{C}$ & $\mathrm{M}$ & I & & \\
\hline Live weight $(\mathrm{g})^{\ddagger}$ & 1135 & 1190 & 1182 & 65 & \\
\hline Feed intake $(g / \text { day })^{\ddagger}$ & 125.6 & 129.8 & 127.4 & 7.6 & \\
\hline \multicolumn{6}{|l|}{ TTAD coefficients (\%) } \\
\hline Organic matter & 77.1 & 72.7 & 77.2 & 4.0 & \\
\hline Crude protein & 86.0 & 83.5 & 85.0 & 4.0 & \\
\hline Ether extract & 92.6 & 93.2 & 93.8 & 1.4 & \\
\hline Starch & 97.9 & 97.4 & 97.8 & 0.5 & \\
\hline $\mathrm{NNCC}^{\S}$ & 96.8 & 96.3 & 97.7 & 1.4 & \\
\hline NDF & 58.5 & 49.9 & 57.3 & 7.3 & \\
\hline ADF & 54.1 & 45.4 & 54.9 & 7.7 & \\
\hline Hemicelluloses (NDF - ADF) & 64.8 & 57.0 & 61.0 & 8.1 & \\
\hline Cellulose (ADF-ADL) & $58.9^{a}$ & $48.3^{b}$ & $58.3^{a}$ & 7.4 & * \\
\hline
\end{tabular}

${ }^{a, b}$ Values in the same row with unlike superscript differ significantly $(P<0.05)$.

${ }^{\dagger}$ RMSE $=$ root mean square error.

${ }^{\ddagger}$ Mean live weight and feed intake during digestibility measurements (from 36 to 40 days old).

${ }^{\S}$ Non-nitrogenous cellular content (NNCC) $=$ OM - CP - NDF. 
(66 mg/kg diet), which is not apparently sufficient for the protection of rabbits against these pathogens. In fact, the resistance of some coccidia (E. magna, E. media, E. perforans) to this drug has been mentioned (Licois, 2004). In spite of non-significant differences in mortality rate among groups during the starter period, morbidity of rabbits as well as the health risk index were affected by dietary treatments used in this study. Both the lowest morbidity $(P=0.05)$ and health risk index $(P=0.03)$ were recorded in rabbits fed the diet supplemented with inulin. Similarly, a protective effect of fructo-oligosaccharides was recorded in animals experimentally infected with enteropathogenic E. coli (Morisse et al., 1993), and also when inulin was added to a high-pectin diet (Volek et al., 2005). The better health status of rabbits fed the diet with inulin observed in our study was apparently associated with the beneficial effect of inulin on the caecal microbial activity (Table 5). In fact, Gidenne and Licois (2005) reported that a high fibre intake improved the resistance of the growing rabbit to a specific enteropathy experimentally induced by an enteropathogenic $E$. coli, in association with a higher caecal fermentative activity and lower caecal $\mathrm{pH}$. When the diets were changed (at 46 days of age), the health risk index increased in the rabbits previously fed with the mannan-oligosaccharide or inulin diet, thus no significant differences in the health status of rabbits were recorded for the whole fattening period (Table 4).

\section{Conclusion}

Supplementation of the starter diet with mannan-oligosaccharide or inulin had no effect on rabbit growth during the whole fattening period. Compared with control and MOS diet, the inulin addition remarkably affected the caecal microbial activity in a beneficial way, which lowered both the morbidity and health risk index of rabbits in the first weeks after weaning. No effect was detected on the mortality of rabbits. The results of our study suggest the importance of using inulin-type fructans in the nutrition of young rabbits. The higher health risk index of rabbits observed after change of diet indicates that prebiotics should be given for a longer time during the fattening period.

\section{Acknowledgements}

This study was supported by the Czech Science Foundation, Project no. 523/03/D011

\section{References}

Association of Official Analytical Chemists 1980. Official methods of analysis. AOAC, Washington, DC.

Conway EJ 1957. Microdiffusion analysis and volumetric error, fourth edition. Crosby Lockwood and Son, London.

Fernández-Carmona J, Blas E, Pascual JJ, Maertens L, Gidenne T, Xiccato G and García J 2005. Recommendations and guidelines for applied nutrition experiments in rabbits. World Rabbit Science 13, 209-228.

Flickinger EA, Van Loo J and Fahey GC 2003. Nutritional responses to the presence of inulin and oligofructose in the diets of domesticated animals: A review. Critical Reviews in Food Science and Nutrition 43, 19-60.
Fonseca AP, Falcão L, Kocher A and Spring P 2004. Effects of dietary mannanoligosaccharide in comparison to oxytetracyclin on performance of growing rabbits. In Proceedings of the eighth World Rabbit Congress. Puebla, Mexico, pp. 829-833.

Gidenne T 2003. Fibres in rabbit feeding for digestive troubles prevention: respective role of low-digested and digestible fibre. Livestock Production Science 81, 105-117.

Gidenne $T$ and Fortun-Lamothe $L$ 2002. Feeding strategy for young rabbits around weaning: a review of digestive capacity and nutritional needs. Animal Science 75, 169-184.

Gidenne T and Fortun-Lamothe L 2004. Growth, health status and digestion of rabbits weaned at 23 or 32 days of age. In Proceedings of the eighth World Rabbit Congress. Puebla, Mexico, pp. 846-852.

Gidenne T and Licois D 2005. Effect of a high fibre intake on the resistance of the growing rabbit to an experimental inoculation with an enteropathogenic strain of Escherichia coli. Animal Science 80, 281-288.

Gidenne T, Jehl N, Segura M and Michalet-Doreau B 2002. Microbial activity in the caecum of the rabbit around weaning: impact of a dietary fibre deficiency and of intake level. Animal Feed Science and Technology 99, 107-118.

Gidenne T, Pinheiro V and Falcão e Cunha L 2000. A comprehensive approach of the rabbit digestion: consequences of a reduction in dietary fibre supply. Livestock Production Science 64, 225-237.

Gutiérrez I, Espinosa A, García J, Carabaño R and De Blas JC 2002a. Effect of levels of starch, fiber, and lactose on digestion and growth performance of early-weaned rabbits. Journal of Animal Science 80, 1029-1037.

Gutiérrez I, Espinosa A, García J, Carabaño R and De Blas JC 2002b. Effects of starch and protein sources, heat processing, and exogenous enzymes in starter diets for early weaned rabbits. Animal Feed Science and Technology $98,175-186$.

Gutiérrez I, Espinosa A, García J, Carabaño R and De Blas JC 2003. Effect of protein source on digestion and growth performance of early-weaned rabbits. Animal Research 52, 461-471.

Juśkiewicz J, Zduńczyk Z and Jankowski J 2003. Effect of adding mannanoligosaccharide to the diet on the performance, weight of digestive tract segments, and caecal digesta parameters in young turkeys. Journal of Animal and Feed Sciences 12, 133-142.

Juśkiewicz J, Zduńczyk Z, Klewicki R and Gomez-Villalva E 2004. Physiological effects of dietary inulin, xylitol and $\beta$-galactosyl-derivatives of sugar alcohols in rat. Acta Alimentaria 33, 303-311.

Juśkiewicz J, Zduńczyk Z and Wróblewska M 2005. The effect of the administration of cellulose and fructans with different degree of polymerization to rats on caecal fermentation and biochemical indicators in the serum. Czech Journal of Animal Science 50, 273-280.

Knudsen KEB 1997. Carbohydrate and lignin contents of plant materials used in animal feeding. Animal Feed Science and Technology 67, 319-338.

Kopečný J and Bartoš S 1990. Activity of hydrolases in the gastrointestinal tract of goats. Small Ruminant Research 3, 25-35.

Lever M 1977. Carbohydrate determination with 4-hydroxybenzoic acid hydrazide (PAHBAH): effect of bismuth on the reaction. Analytical Biochemistry 81, 21-27.

Licois D 2004. Domestic rabbit enteropathies. Proceedings of the eighth World Rabbit Congress. Puebla, Mexico, pp. 385-403.

Lipiński K, Purwin C, Tywończuk J, Zduńczyk Z, Wróblewska M, ŁaniewskaTrokenheim $\measuredangle$ and Warmińska-Radyko I 2005. Effects of feed additives on nutrient digestibility and the bacterial status of faeces in pigs. Journal of Animal and Feed Sciences 14, (suppl. 1) 369-372.

Luick BR, El-Sayaad GAE and Cheeke PR 1992. Effect of fructooligosaccharides and yeast culture on growth performance of rabbits. Journal of Applied Rabbit Research 15, 1121-1128.

Maertens L, Perez JM, Villamide M, Cervera C, Gidenne T and Xiccato G 2002. Nutritive value of raw materials for rabbits: EGRAN Tables 2002. World Rabbit Science 10, 157-166.

Maertens L, Aerts JM and De Boever J 2004. Degradation of dietary oligofructose and inulin in the gastro-intestinal tract of the rabbit and the effects on caecal pH and volatile fatty acids. World Rabbit Science 12, 235-246.

Marounek M, Vovk SJ and Skřivanová V 1995. Distribution of activity of hydrolytic enzymes in the digestive tract of rabbits. British Journal of Nutrition $73,463-469$. 
Meyer D, van Nuenen M and Venema K 2004. The effect of various inulins and Clostridium difficile on the metabolic activity and composition of the human colonic microbiota in vitro. In Dietary fibre: bio-active carbohydrates for food and feed (ed. JW Van der Kamp, J NG Asp, MillerJones and G Schaafsma), pp. 237-253, Wageningen Academic Publishers, The Netherlands.

Morisse JP, Maurice R, Boilletot E and Cotte JP 1993. Assessment of the activity of a fructo-oligosaccharide on different caecal parameters in rabbits experimentally infected with E. coli 0.103. Annales de Zootechnie 42, 81-87.

Nicodemus N, Pérez-Alba L, Carabaño R, De Blas JC, Badiola I, Pérez de Rozas A and García J 2004. Effect of level of fibre and level of ground of fibre sources on digestion and ileal and caecal characterization of microbiota of early-weaned rabbits. In Proceedings of the eighth World Rabbit Congress. Puebla, Mexico, pp. 928-929.

Pascual JJ 2001. Early weaning of young rabbits: a review. World Rabbit Science 9, 165-170.

Perez JM, Lebas F, Gidenne T, Maertens L, Xiccato G, Parigi-Bini R, Dalle Zotte A, Cossu ME, Carazzolo A, Villamide MJ, Carabaño R, Fraga MJ, Ramos MA, Cervera C, Blas E, Fernandez J, Falcao e Cunha L and Bengala Freire J 1995. European reference method for in vivo determination of diet digestibility in rabbits. World Rabbit Science 3, 41-43.

Pinheiro V, Alves A, Mourão JL, Guedes CM, Pinto L, Spring P and Kocher A 2004. Effect of mannan oligosaccharides on the ileal morphometry and caecal fermentation of growing rabbits. In Proceedings of the eighth World Rabbit Congress. Puebla, Mexico, pp. 936-941.
Scapinello C, de Faria HG, Furlan AC and Michelan AC 2001. Effect of the utilization of oligosaccharide mannose and acidifiers on growing rabbits performance. Revista Brasileira de Zootecnia 30, 1272-1277.

Spring P, Wenk C, Dawson KA and Newman KE 2000. The effects of dietary mannanoligosaccharides on cecal parameters and the concentrations of enteric bacteria in the ceca of salmonella-challenged broiler chicks. Poultry Science 79, 205-211.

Statistical Analysis Systems Institute 2001. SAS version 8.2. SAS Inst. Inc., Cary, NC.

Van Soest PJ, Robertson JB and Lewis BA 1991. Methods for dietary fiber, neutral detergent fiber, and non starch polysaccharides in relation to animal nutrition. Journal of Dairy Science 74, 3583-3597.

Volek Z, Marounek M and Skrivivanová V 2005. Replacing starch by pectin and inulin in diet of early-weaned rabbits: effect on performance, health and nutrient digestibility. Journal of Animal and Feed Sciences 14, 327-337.

Volek Z, Marounek M and Skřivanová V 2006. Technical note: Health status and growth performance of rabbits fed diets with different starch level during the post-weaning period. World Rabbit Science 14, 27-31.

Xiccato G, Trocino A, Sartori A and Queaque PI 2003. Effect of weaning diet and weaning age on growth, body composition and caecal fermentation of young rabbits. Animal Science 77, 101-111.

Xiccato G, Trocino A, Sartori A and Queaque PI 2004. Effect of parity order and litter weaning age on the performance and body energy balance of rabbit does. Livestock Production Science 85, 239-251. 